\title{
AGRONOMIC PERFORMANCE AND WATER USE EFFICIENCY OF IRRIGATED CACTUS PEAR CULTIVARS ${ }^{1}$
}

\author{
IGOR NOGUEIRA DE CASTRO ${ }^{2 *}$, SILVÂNIO RODRIGUES DOS SANTOS ${ }^{3}$, MARCOS KOITI KONDO $^{3}$, VICTOR \\ MARTINS MAIA ${ }^{3}$, CARLOS CÉSAR RODRIGUES DOS SANTOS ${ }^{4}$
}

\begin{abstract}
Cactus pear is an alternative for animal feed in the semiarid region, and its productive characteristics can be improved with little irrigation. The objective of this work was to assess the agronomical performance and water use efficiency (WUE) of two cactus pear cultivars subjected to different irrigation water depths and define the best material genetic material for irrigated conditions in the semiarid region of the state of Minas Gerais (MG), Brazil. The experiment was conducted in Montalvânia, MG, during one year (2017-2018) using six treatments consisting of irrigation water depths based on the reference evapotranspiration $\left(\mathrm{ET}_{0}\right)$ (without irrigation, $15 \%, 30 \%, 45 \%, 60 \%$, and $75 \% \mathrm{ET}_{0}$ ) and two genetic materials (Opuntia ficus-indica Mill. cv. Gigante, and Nopalea cochenillifera Salm-Dyck cv. Miúda). A randomized block design was used, in a with split-plot arrangement consisting of irrigation treatments in the plots and genetic materials in the subplots, with four replications. Growth evaluations were carried out from the third month after planting to the end of the growing cycle. Production variables and WUE were evaluated at the harvest. The irrigation water depths affected the growth variables, significantly $(\mathrm{p}<0.05)$. The water depths of $40 \%$ to $50 \% \mathrm{ET}_{0}$ provided higher fresh and dry matter yields; the cultivar Miúda showed better performance than the Gigante. The WUE was affected by the irrigation water depths; the cultivar Miúda was the best option for the crop.
\end{abstract}

Keywords: Opuntia ficus-indica mill. Nopalea cochenillifera salm-dyck. Yield. Water regime.

\section{DESEMPENHO AGRONÔMICO E EFICIÊNCIA DE USO DA ÁGUA EM CULTIVARES DE PALMA FORRAGEIRA IRRIGADA}

RESUMO - A palma forrageira é uma alternativa para alimentação animal na região semiárida, sendo possível aprimorar suas características produtivas com um mínimo de irrigação. Objetivou-se analisar o desempenho agronômico e a eficiência de uso da água (EUA) de duas cultivares de palma forrageira submetidas a diferentes níveis de irrigação, bem como definir qual o melhor material genético para condições irrigadas no semiárido mineiro. O experimento foi conduzido em Montalvânia-MG durante um ano (2017-2018) envolvendo seis tratamentos de lâminas de irrigação correspondentes a frações da evapotranspiração de referência $\left(E_{0}\right)\left(T_{1}\right.$, sem irrigação; $\mathrm{T}_{2}, 15 \% ; \mathrm{T}_{3}, 30 \% ; \mathrm{T}_{4}, 45 \% ; \mathrm{T}_{5}, 60 \%$ e, $\mathrm{T}_{6}, 75 \%$ da $\mathrm{ET}_{0}$ ) e dois materiais genéticos (Gigante Opuntia fícus-indica Mill. e Miúda - Nopalea cochenillifera Salm-Dyck). Utilizou-se o delineamento em blocos casualizados em esquema de parcelas subdivididas, em que as parcelas foram os tratamentos de irrigação e as subparcelas foram os materiais genéticos, com quatro repetições. A partir do terceiro mês após o plantio e durante um ciclo de cultivo efetuaram-se as avaliações de crescimento e, na colheita foram avaliadas as variáveis de produção e a EUA. Constatou-se que as lâminas de irrigação influenciaram significativamente $(\mathrm{p}<0,05)$ as variáveis de crescimento. As lâminas de 40 a $50 \%$ da $\mathrm{ET}_{0}$ proporcionaram maior produtividade de matéria verde e matéria seca e a cultivar Miúda superou a 'Gigante'. A EUA foi influenciada pelas lâminas de irrigação, sendo a cultivar Miúda a melhor opção para o cultivo.

Palavras-chave: Opuntia fícus-indica mill.. Nopalea cochenillifera salm-dyck. Rendimento agronômico. Regime hídrico.

\footnotetext{
${ }^{*}$ Corresponding author

${ }^{1}$ Received for publication in $11 / 02 / 2019$; accepted in $02 / 19 / 2020$.

Paper extracted from the master's dissertation of the first author.

${ }^{2}$ Master's degree in Master and Doctorate in Crop Production, Universidade Estadual de Montes Claros, Janaúba, MG, Brazil; igornogueira -ig@hotmail.com - ORCID: 0000-0002-4586-0122.

${ }^{3}$ Department of Agricultural Sciences, Universidade Estadual de Montes Claros, Janaúba, MG, Brazil; silvanio.santos@unimontes.br ORICD: 0000-0003-0245-9184, marcos.kondo@unimontes.br - ORCID: 0000-0001-6875-4907, victor.maia@unimontes.br - ORCID: 0000-0002-6624-8805.

${ }^{4}$ Farmer, Montalvânia, MG, Brazil; c.cesars@gmail.com - ORCID: 0000-0003-2722-2212.
} 


\section{INTRODUCTION}

Livestock is an important activity developed in the semiarid region, especially bovine, caprine, and ovine rearing. These animals usually feed on native plants that have $\mathrm{C}_{3}$ and $\mathrm{C}_{4}$ photosynthetic process, whose yield has been compromised in semiarid regions due to water deficits. Thus, the use of forage plants with high water use efficiency and tolerance to droughts (WUE) is necessary. In these conditions, plant species with crassulacean acid metabolism (CAM) are a good option to increase forage availability for animals. Among these species is the cactus pear (Opuntia spp.), a cetacean species that presents high water use efficiency and tolerance to long drought periods (SILVA et al., 2015; MARQUES et al., 2017; SOUZA et al., 2018; CARVALHO et al., 2017).

Cactus pear has morphophysiological characteristics that allow them to thrive under the physical environmental limitations predominant in semiarid regions. These characteristics include thick cuticles; large vacuoles; low stomatal size, density, and opening frequency; leaves modified into spines; substomatal chamber; chlorophyllous parenchyma; well-developed aquiferous system and mucilaginous cells (AZEVEDO et al., 2013). The most used species for planting are from the genera Opuntia and Nopalea, especially Opuntia ficus-indica Mill. and Nopalea cochenillifera Salm-Dyck (SILVA et al., 2017).

The management adopted is important to reach the productive potential of these crops, which includes the use of improved clones, soil fertilization, and adequate planting technique, weed control, and water depths (SILVA et al., 2014a). The irrigation management is also important due to the supplying of the water need of the crop (MARTIN et al., 2012), which requires management practices that provide benefits to the production system (CRUZ NETO et al., 2017).

Therefore, studies on the cactus pear performance under different soil water availability conditions are needed to define its water demand and maximize its yield (AMORIM et al., 2017). Although irrigation of cactus pear plants is an incipient practice in the semiarid region of Brazil, there are reports of success in the states of Rio Grande do Norte and Pernambuco (QUEIROZ et al., 2015; LIMA et al., 2016) and in other regions of the world.

The vegetative growth of these plants is strongly related to the soil water content due to the dependence of major physiological and biochemical processes on water. The measuring of growth variables, yield, and water use efficiency in different water availability conditions is an alternative to show response patterns of plants and contribute to the decision making for management of different species (ARAÚJO JÚNIOR et al., 2019) and identification of characteristics that affect the most the production (PEREIRA et al., 2015). These studies are important for cactus pear, since these determinations contribute to the improvement of water use in the local agriculture.

In this context, the objective of this work was to assess the agronomical performance and water use efficiency (WUE) of two cactus pear cultivars subjected to different water depths and define the best material genetic for irrigated conditions in the semiarid region of the state of Minas Gerais, Brazil.

\section{MATERIAL AND METHODS}

The experiment was conducted in a rural property in the municipality of Montalvânia, in the semiarid region of state of Minas Gerais, Brazil, from September 2017 to November 2018. The experiment area was located at the geographical coordinates $14^{\circ} 19^{\prime} 21.73^{\prime \prime} \mathrm{S}$ and $44^{\circ} 28^{\prime} 39.45^{\prime \prime} \mathrm{W}$, at an altitude of $492 \mathrm{~m}$. The soil of the experiment area was classified as a Typic Hapludox, which was previously used for pastures and, subsequently, for bean, maize, and watermelon crops, and was fallow for six years. The climate of the region was classified as Aw, according to the Köppen classification (ALVARES et al., 2013).

Soil samples from the $0-0.2$ and $0.2-0.4 \mathrm{~m}$ layers were collected before the experiment implementation for chemical characterization, according to the methodology described by Teixeira et al. (2017) (Table 1).

Table 1. Chemical characteristics of the soil (0-0.2 m layer) of the experimental area.

\begin{tabular}{|c|c|c|c|c|c|c|c|c|c|c|c|c|}
\hline $\mathrm{pH}$ & $\begin{array}{c}\text { Organic } \\
\text { Matter }\end{array}$ & $\mathrm{P}$ & $\mathrm{K}$ & $\mathrm{Na}$ & $\mathrm{Mg}$ & $\mathrm{Al}$ & $\mathrm{H}+\mathrm{Al}$ & B & $\mathrm{Cu}$ & $\mathrm{Fe}$ & $\mathrm{Mn}$ & $\mathrm{Zn}$ \\
\hline & dag kg ${ }^{-1}$ & & & \multicolumn{4}{|c|}{$\mathrm{cmol}_{\mathrm{c}} \mathrm{dm}^{-3}$} & \multicolumn{5}{|c|}{$\mathrm{mg} \mathrm{dm}^{-3}$} \\
\hline 6.3 & 2.4 & 9.1 & 362 & 0.2 & 1.7 & 0.0 & 1.6 & 0.3 & 2.4 & 20.9 & 61.7 & 5.3 \\
\hline
\end{tabular}


The field experiment was conducted using six treatments consisted of irrigation water depths based on the reference evapotranspiration $\left(\mathrm{ET}_{0}\right)$ (without irrigation, $15 \%, 30 \%, 45 \%, 60 \%$, and $\left.75 \% \mathrm{ET}_{0}\right)$ and two genetic materials of cactus pear (Opuntia ficusindica Mill. cv. Gigante, and Nopalea cochenillifera Salm-Dyck cv. Miúda). A randomized block design was used, in a split-plot arrangement, with the irrigation treatments in the plots, and the genetic materials in the subplots, with four replications. Each plot was constituted of two $3.25 \mathrm{~m}$ double rows of plants, with spacing of $0.25 \mathrm{~m}$ between plants, $0.5 \mathrm{~m}$ between simple rows, and $1.5 \mathrm{~m}$ between double rows, totaling 26 plants per subplot; the seven central plants were considered for the evaluations.

The experiment area was prepared for planting with plowing and harrowing. The plantlets were planted with half of the cladode buried into the soil. The cladodes were planted in furrows with depth of $0.20 \mathrm{~m}$. Soil fertilization at planting was carried out, based on the soil chemical analysis, using $20 \mathrm{Mg} \mathrm{ha}{ }^{-1}$ of ovine manure (organic fertilization) and $75 \mathrm{~kg} \mathrm{ha}^{-1}$ of $\mathrm{N}, 100 \mathrm{~kg} \mathrm{ha}^{-1}$ of $\mathrm{P}_{2} \mathrm{O}_{5}$, and $75 \mathrm{~kg} \mathrm{ha}^{-1}$ of $\mathrm{K}_{2} \mathrm{O}$ (chemical fertilization); $\mathrm{P}$ was from a NPK formulation 4-30-10, and $\mathrm{N}$ and $\mathrm{K}_{2} \mathrm{O}$ were complemented using urea and $\mathrm{KCl}$, respectively, according to the recommendation of
Donato et al. (2017). Cultural practices during the experiment were carried out to provide ideal conditions for the development of the crops. Weeds were controlled using manual weeding, mainly in the rainy periods. These rainy periods caused the death of $32.84 \%$ cactus pear plants, $11.05 \%$ from the cultivar Gigante, and $21.79 \%$ from the cultivar Miúda.

The water depths were applied weekly using drip irrigation based on the reference evapotranspiration $\left(\mathrm{ET}_{0}\right)$, according to the equation of Hargreaves and Samani (1985) modified by Allen et al. (2006). Data of maximum and minimum temperatures were obtained from a meteorological station in the experimental area. $\mathrm{ET}_{0}$ data were recorded daily and accumulated for seven days to calculate the irrigation time, according to Mantovani et al. (2009).

The water used presented electrical conductivity of $0.03 \mathrm{dS} \mathrm{m}^{-1}$. Pressure compensating drippers were used (pressure of 50 to $400 \mathrm{kPa}$ ), which were placed in the line and spaced $0.40 \mathrm{~m}$ apart, with flows of $2,4,6,8$, and $10 \mathrm{~L} \mathrm{~h}^{-1}$, according to the treatments. The measured rainfall and estimated irrigation water depths by the irrigation times are presented in (Table 2).

Table 2. Water depths applied $(\mathrm{mm})$ and total rainfall $(\mathrm{mm})$ during the first production cycle of cactus pear of the cultivars Gigante and Miúda in each irrigation water depth based on the reference evapotranspiration $\left(\mathrm{ET}_{0}, \%\right)$. (Montalvânia - MG, 2017/2018).

\begin{tabular}{cccc}
\hline $\mathrm{ET}_{0}$ & Water depths applied & $\begin{array}{c}\text { Total } \\
\text { rainfall }\end{array}$ & $\begin{array}{c}\text { Accumulated } \\
\text { water depth }\end{array}$ \\
\hline 0 & 0 & 680.9 & 680.9 \\
15 & 177.9 & 680.9 & 858.8 \\
30 & 355.8 & 680.9 & 1036.7 \\
45 & 533.7 & 680.9 & 1214.6 \\
60 & 711.6 & 680.9 & 1392.5 \\
75 & 889.5 & 680.9 & 1570.4 \\
\hline
\end{tabular}

The irrigation treatments were differentiated at 60 days after planting (DAP). The growth evaluations started at 90 DAP and ended at one year after planting (August 2018). The variables plant height $(\mathrm{PH})$, number of cladodes per plant $(\mathrm{NCP})$, cladode length $(\mathrm{CL})$, cladode width $(\mathrm{CW})$, and cladode area index (CAI) were measured every 30 days during ten months.

The CAI was estimated using the data obtained for CL and CW. The cladode area (AC) was determined according to method described by Pinto et al. (2002), (Equation 1).

$$
A C=(C L * C W * 0.693) * 2
$$

where $A C$ is the cladode area $\left(\mathrm{cm}^{2}\right) ; C L$ is the cladode length $(\mathrm{cm}) ; C W$ is the cladode width $(\mathrm{cm})$; and 0.693 is the correction factor due to the elliptical form of the cladode.
The AC was used to calculate the CAI (Equation 2), allowing to measure the total area of the cladodes of the plants, considering the two sides of the cladodes and the area occupied per plant $\left(\mathrm{m}^{2}\right.$ of area of cladode per $\mathrm{m}^{2}$ of soil), analyze the photosynthetic radiation interception by the cactus pear, and determine the active photosynthetically area of the plant (SILVA et al., 2014c).

$$
C A I=\frac{A C}{A R P}
$$

where $C A I$ is the cladode area index $\left(\mathrm{m}^{2} \mathrm{~m}^{-2}\right)$, and $A R P$ is the soil area intended for the plant $\left(\mathrm{m}^{2}\right)$.

All plants used for evaluation in the subplots were harvested in November 2018, by cutting all cladodes separately, preserving only the cladode used for the planting. The harvested cladodes were 
weighed and their fresh matter yield (FMY) $\left(\mathrm{Mg} \mathrm{ha}^{-1}\right)$ was determined.

The dry matter yield (DMY) $\left(\mathrm{Mg} \mathrm{ha}^{-1}\right)$ was determined by multiplying the dry matter of the treatment by the FMY.

The water use efficiency was determined using the DMY and the accumulated water depths during the crop cycle (Equation 3).

$$
W U E=\frac{Y I E L D}{W D}
$$

where $W U E$ is the water use efficiency $\left(\mathrm{kg} \mathrm{ha} \mathrm{mm}^{-1}\right)$, YIELD is the dry matter yield $\left(\mathrm{kg} \mathrm{ha}{ }^{-1}\right)$; and WD is the water depth applied + accumulated rainfall ( $\mathrm{mm}$ ) (Table 2 ).

The data of growth, production, and WUE were subjected to analysis of variance and to evaluation of interactions with up to $5 \%$ significance. Quantitative sources of variation (water depth and DAP) were subjected to regression analysis at $5 \%$ significance, and the qualitative source of variation (cultivar) was compared by the $\mathrm{F}$ test at $5 \%$ significance, using the statistic programs Sisvar (FERREIRA, 2014) and SigmaPlot ${ }^{\circledR}$, trial version. The regression model that best represented the biological phenomenon involved was found, presenting the highest coefficient of determination $\left(\mathrm{R}^{2}\right)$ and significance of regression parameters by the $\mathrm{t}$ Student test $(\mathrm{p}<0.05)$. Non-linear Gaussian regression models were used to represent $\mathrm{PH}, \mathrm{NCP}$, and CAI, according to Equation 4.

$$
\hat{\mathrm{Y}}=\frac{a}{\left(\frac{1+\exp (-(x-x 0))}{b}\right)}
$$

where $a$ is the maximum accumulation value; $x 0$ is the $x$ value in which the curve inflection begins (inflection point in the which the maximum accumulation rate of value $y$ is found); and $b$ is the $x$ range in which there is the highest variation in $\mathrm{y}$.

\section{RESULTS AND DISCUSSION}

There was a triple interaction between the cladode length (CL) and width (CW). The interaction between cultivar (CTV) and days after planting (DAP) was significant for plant height (PH), number of cladodes per plant (NCP), and cladode area index $(\mathrm{CAI})$. The interaction between irrigation water depths based on reference evapotranspiration $\left(\mathrm{ET}_{0}\right)$ and days after planting (DAP) was significant only for plant height $(\mathrm{PH})$. The days after planting (DAP) and cultivar (CTV) presented isolate effects on all variables (Table 3 ).

Table 3. Analysis of variance for plant height $(\mathrm{PH}, \mathrm{cm})$, number of cladodes per plant $(\mathrm{NCP})$, cladode length $(\mathrm{CL}, \mathrm{cm})$, cladode width $(\mathrm{CW}, \mathrm{cm})$, and cladode area index (CAI) of cactus pear of the cultivars Gigante and Miúda (CTV) grown

\begin{tabular}{|c|c|c|c|c|c|c|}
\hline \multirow{2}{*}{ Source of variation } & \multirow{2}{*}{$\mathrm{DF}$} & \multicolumn{5}{|c|}{ Mean square } \\
\hline & & $\mathrm{PH}$ & $\mathrm{NCP}$ & $\mathrm{CL}$ & $\mathrm{CW}$ & CAI \\
\hline Block & 3 & $1206.53 *$ & $341.33 \mathrm{~ns}$ & $4.16^{\mathrm{ns}}$ & $1.06^{\mathrm{ns}}$ & $19.77^{\mathrm{ns}}$ \\
\hline $\mathrm{ET}_{0}$ & 5 & $436.63^{\mathrm{ns}}$ & $20.15^{\mathrm{ns}}$ & $82.09^{\mathrm{ns}}$ & $27.31^{\mathrm{ns}}$ & $5.39^{\mathrm{ns}}$ \\
\hline Error (a) & 15 & 321.09 & 186.19 & 34.86 & 12.79 & 6.71 \\
\hline CTV & 1 & $15752.34 * *$ & $17569.20 * *$ & $6026.85 * *$ & $4024.80 * *$ & $40.04 *$ \\
\hline $\mathrm{ET}_{0} \times \mathrm{CTV}$ & 5 & $644.98^{\mathrm{ns}}$ & $129.97^{\mathrm{ns}}$ & $40.37^{\mathrm{ns}}$ & $12.58^{\mathrm{ns}}$ & $8.03^{\mathrm{ns}}$ \\
\hline Error (b) & 18 & 314.15 & 158.58 & 29.46 & 9.26 & 6.44 \\
\hline DAP & 9 & $12097.52 * *$ & $2909.65 * *$ & $33.48 * *$ & $16.19 * *$ & $120.86 * *$ \\
\hline $\mathrm{ET}_{0} \times \mathrm{DAP}$ & 45 & $59.64 * *$ & $5.00^{\mathrm{ns}}$ & $2.78^{\mathrm{ns}}$ & $1.43^{\mathrm{ns}}$ & $0.56^{\mathrm{ns}}$ \\
\hline $\mathrm{CTV} \times \mathrm{DAP}$ & 9 & $55.84 *$ & $1105.35 * *$ & $42.96 * *$ & $1.36^{\mathrm{ns}}$ & $7.88 * *$ \\
\hline $\mathrm{ET}_{0} \times \mathrm{CTV} \times \mathrm{DAP}$ & 45 & $28.44^{\mathrm{ns}}$ & $12.51^{\mathrm{ns}}$ & $10.05 * *$ & $2.05 * *$ & $0.54^{\mathrm{ns}}$ \\
\hline Error $(\mathrm{c})$ & 324 & 23.75 & 19.59 & 5.09 & 1.15 & 0.75 \\
\hline CV $1(\%)$ & & 28.14 & 120.53 & 28.53 & 36.53 & 112.55 \\
\hline CV $2(\%)$ & & 27.84 & 111.24 & 26.23 & 31.09 & 110.28 \\
\hline CV $3(\%)$ & & 7.66 & 39.10 & 10.91 & 10.98 & 37.69 \\
\hline Overall mean & & 63.66 & 11.32 & 20.69 & 9.79 & 2.30 \\
\hline
\end{tabular}
under different irrigation water depths, based on reference evapotranspiration $\left(\mathrm{ET}_{0}, \%\right)$, over 360 days after planting (DAP).

$\mathrm{DF}=$ degrees of freedom; $\mathrm{ns}=$ not significant, $* *=$ significant at $1 \%$, and $*=$ significant at $5 \%$ by the $\mathrm{F}$ test 
$\mathrm{PH}$ increased with increases in water depths at 270,300,330, and 360 days after planting, fitting significantly to a Gaussian non-linear model (Figure 1). Only in the last months of the crop cycle, the irrigation water depths $\left(\% \mathrm{ET}_{0}\right)$ had high effect on $\mathrm{PH}$, reaching the maximum accumulated $\mathrm{PH}$ with water depth increases of 49.20 (270 DAP), 48.25 (300 DAP), 34.59 (330 DAP), and 29.26\% (360 DAP) of $\mathrm{ET}_{0}$ (Figure 1). A single irrigation with water deficit in the last four months of the crop cycle is not enough to increase $\mathrm{PH}$, since higher $\mathrm{PH}$ were found up to 240 DAP for a water depth of $30 \% \mathrm{ET}_{0}$, with increase of $0.1746 \mathrm{~cm}$ for each increase in water depth (Figure 2A). The highest water depths increased $\mathrm{PH}$ from 270 days up to the end of the crop cycle (Figure 2B). Pereira et al. (2015) evaluated the growth rates for $\mathrm{PH}$ in the state of Pernambuco, Brazil, and found that all rates presented significant increases in the last months of growth because of more expressive rainfall events.

Irrigation with water deficit does not compromise $\mathrm{PH}$, and the use of $30 \% \mathrm{ET}_{0}$ up to 240 DAP and $75 \% \mathrm{ET}_{0}$ in the last months is viable for this variable. However, increases in water depth above $75 \% \mathrm{ET}_{0}$ cannot increase $\mathrm{PH}$, indicating that a higher water availability does not increase the development of plants, mainly in cactus pear species, whose low water consumption increases soil moisture (BAJGAIN et al., 2015)

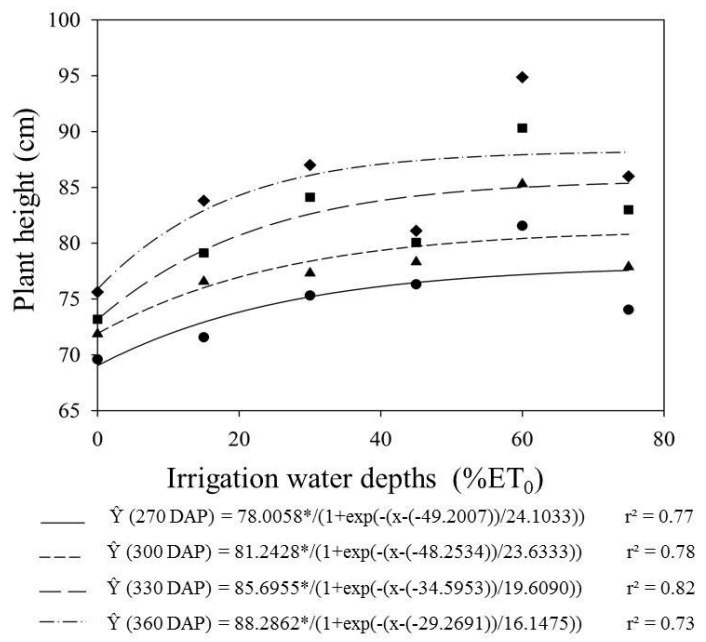

Figure 1. Cactus pear plant height as a function of irrigation water depths $\left(\% \mathrm{ET}_{0}\right)$ applied through drip irrigation at 270 , 300,330 , and 360 days after planting (DAP).
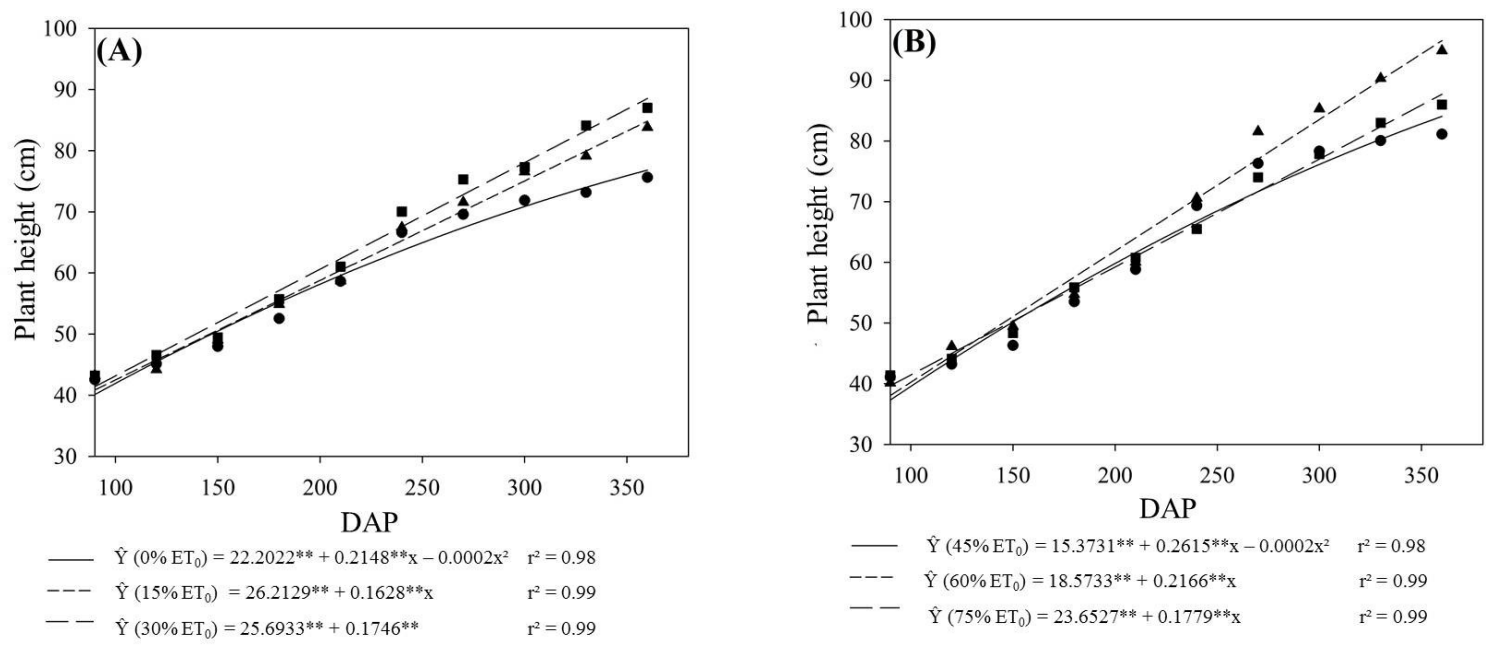

Figure 2. Cactus pear plant height over the first crop cycle (days after planting - DAP) for water depts based on the $\mathrm{ET}_{0}$ applied through drip irrigation $-0 \%, 15 \%$, and $30 \%(\mathrm{~A}), 45 \%, 60 \%$, and $75 \% \mathrm{ET}_{0}(\mathrm{~B})$. 
The cactus pear cultivars presented different $\mathrm{PH}$ due to their intrinsic characteristics (Figure 3A). The data of $\mathrm{PH}$ over the crop cycle of both cultivars fitted to simple linear models, reaching heights of 90 $\mathrm{cm}$ (Gigante) and $80 \mathrm{~cm}$ (Miúda) (Figure 3A). However, their increase per water depth increased were similar. Cultivars of the genus Opuntia present higher PH than cultivars of the genus Nopalea (SILVA et al., 2015). Oliveira Júnior et al. (2009) found $\mathrm{PH}$ of 67 to $76 \mathrm{~cm}$ the cultivar Gigante in Soledade, state of Paraiba, Brazil, depending on the crop spacing, under rainfall of $224 \mathrm{~mm}$ up to 330 DAP.

The number of cladodes per plant (NCP) reached maximum accumulation at 206 DAP for the cultivar Gigante, and at 236 DAP for the cultivar Miúda. The highest NCP for the cultivars Gigante (9.45) and Miúda (36.99) were found at 360 DAP (Figure 3B). The NCP of the cultivar Miúda was

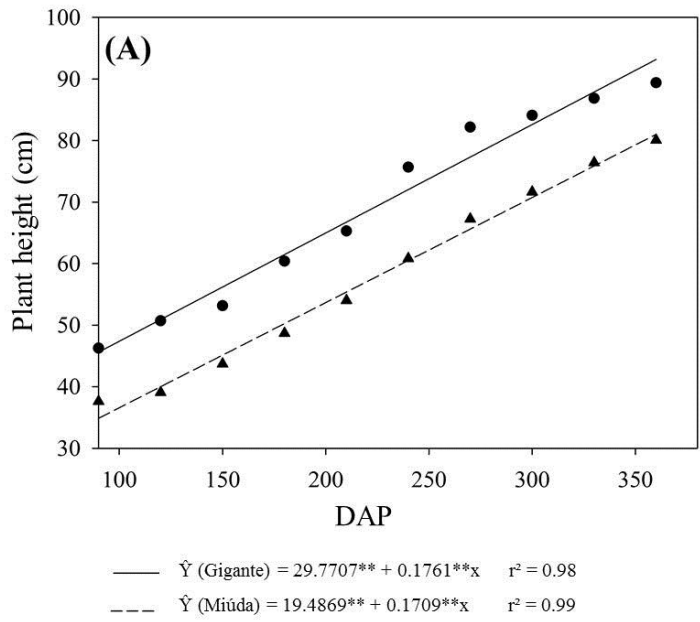

higher because it produces small plants, with very ramified stem that contains great quantity of small cladodes (VASCONCELOS et al., 2009). Cavalcante et al. (2014) found similar results in the state of Sergipe, Brazil, with cactus pear plants of the cultivar Gigante presenting 17 cladodes per plant, and those of the cultivar Miúda presenting 81.5 cladodes at 24 months after planting. This result related to growth characteristics of plants of genus Nopalea. PH and NCP are correlated, depending on the cultivar, because of the cladode distribution in the plant; at some time of the crop cycle, $\mathrm{PH}$ of cactus pear plants does not increase and NCP increases to the plant sides by ramification. As the plant grow, the emission of first order cladodes is stabilized and the emission of cladodes of higher orders is prioritized (RAMOS et al., 2011), depending on the plant's age.

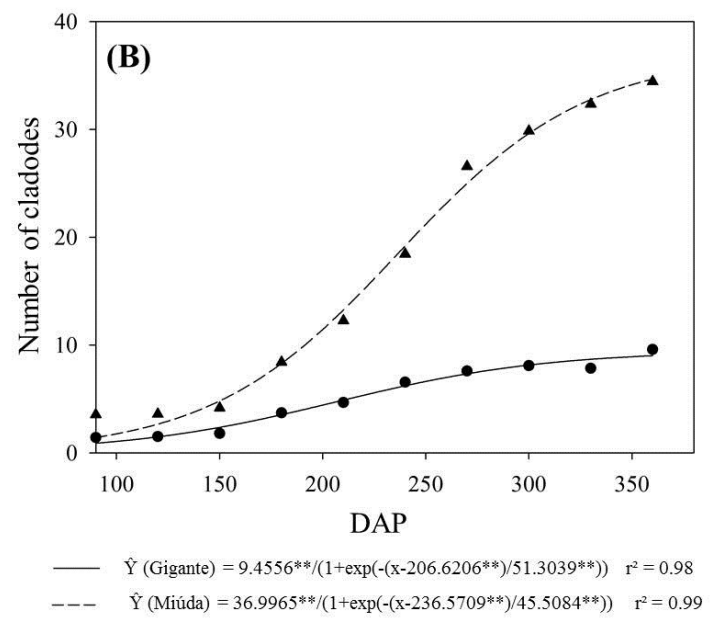

Figure 3. Cactus pear plant height (A) and number of cladodes (B) over the first crop cycle (days after planting - DAP) for the cultivars Gigante and Miúda.

The cladode length (CL) of the cultivar Gigante increased in $0.0242,0.0139$, and $0.0213 \mathrm{~cm}$ day $^{-1}$ for $0 \%, 15 \%$ and $60 \% \mathrm{ET}_{0}$, respectively (Figures 4A and 4B), whereas the cultivar Miúda had decreases over the crop cycle of $0.0168,0.0122$, and $0.0119 \mathrm{~cm} \mathrm{day}^{-1}$ for the same irrigation water depths (Figures $4 \mathrm{C}$ and $\mathrm{D}$ ). The irrigation water depths of 30,45 , and $75 \% \mathrm{ET}_{0}$ did not fit to the models tested, with means of $26.85,24.66$, and $16.74 \mathrm{~cm}$, respectively, for the cultivar Gigante; and 17.51, 16.85 , and $16.74 \mathrm{~cm}$, respectively, for the cultivar Miúda. The cladode width $(\mathrm{CW})$ of the cultivar Gigante increased at $0.0127,0.006$, and $0.012 \mathrm{~cm}$ day $^{-1}$ for the $0 \%, 15 \%$ and $60 \% \mathrm{ET}_{0}$, respectively (Figures $5 \mathrm{~A}$ and $\mathrm{B}$ ); and $\mathrm{CW}$ of the cultivar Miúda fitted to a linear model, with increases of 0.0087 and $0.0047 \mathrm{~cm} \mathrm{day}^{-1}$ over the crop cycle for the irrigation water depths of $45 \%$ and $60 \% \mathrm{ET}_{0}$, respectively. The data of the water depths $30 \%, 45 \%$ and $75 \% \mathrm{ET}_{0}$ did not fit to the models tested for the cultivar Gigante, presenting means of $14.22,12.73$, and $12.70 \mathrm{~cm}$. The data of the water depths $0 \%, 15 \%, 30 \%$, and $75 \%$ $\mathrm{ET}_{0}$ did not fit to the models for the cultivar Miúda, presenting means of $6.67,6.81,7.32$, and $7.70 \mathrm{~cm}$, respectively.

Despite the decrease in CL in the cultivar Miúda, this is explained by characteristics of crassulacean acid metabolism (CAM) plants, whose anatomical and physiological systems enable them to function as $\mathrm{C}_{3}$ plants under high water supply, with the complex process done during the day (NOBEL, 2001). The cladodes bend as a response to that, which can decrease their size, a morphological evidence of this characteristic. This was observed sometimes in the present experiment; however, Santos et al. (2013) evaluated cactus pear plants in Pernambuco, where the annual rainfall is over 1.000 $\mathrm{mm}$ and found that their photosynthetic mechanism 
is exclusively CAM. Thus, studies under this situation are needed. The CL of the cultivar Gigante was higher than that of the Miúda due to morphological characteristic of the clone used. According to Pereira et al. (2015), clones of the genus Opuntia show better evolution of biometric
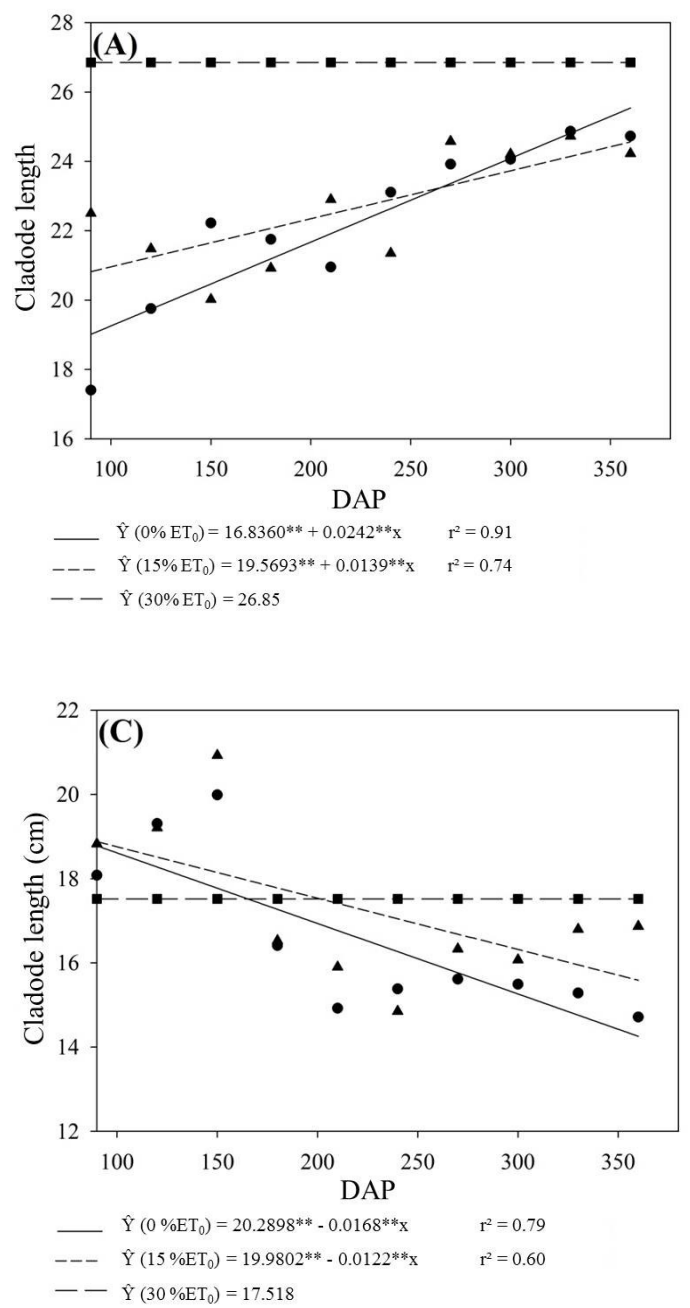

variables than the cultivar Miúda in the Brazilian semiarid conditions. Thus, plants of the cultivar Miúda somewhat compensate the lower development of their cladodes by a higher emission due to the size of the cladodes, with consequent increase in cladode area index (CAI) (Figure 6).
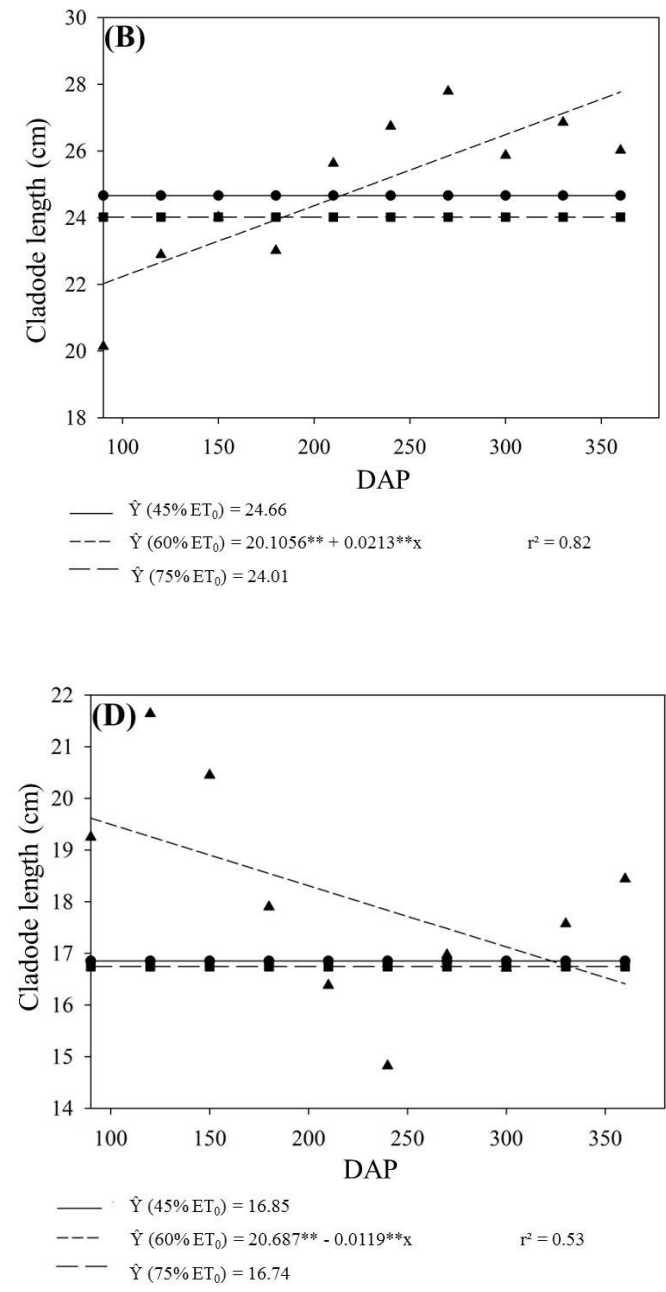

Figure 4. Cladode length over the crop cycle (days after planting - DAP) for water depts based on the $\mathrm{ET}_{0}$ applied through drip irrigation $-0 \%, 15 \%$, and $30 \%(\mathrm{~A}), 45 \%, 60 \%$, and $75 \% \mathrm{ET}_{0}(\mathrm{~B})$ for the cultivar Gigante; and $0 \%, 15 \%$, and $30 \%(\mathrm{C})$, $45 \%, 60 \%$, and $75 \% \mathrm{ET}_{0}$ (D) for the cultivar Miúda.

Plants of the cultivar Gigante had higher cladode width and length in the experimental conditions, denoting a higher water accumulation capacity, since turgidity is an important attribute of CAM plants. Thus, they show morphologically or anatomically, by their thick cladodes, the effect on cladode length and width, with presence of vacuoles full of water in photosynthetic cells and presence of several layers of water-storing cells (TAIZ; ZEIGER, 2017). The mature cladodes are usually thicker, since their higher part is constituted by a whitish water-storing tissue (NOBEL, 2001), indicating a higher adaptation potential of cultivar Gigante to low soil water availability conditions than the cultivar Miúda, by presenting higher water reserve capacity (PEREIRA et al., 2015). 

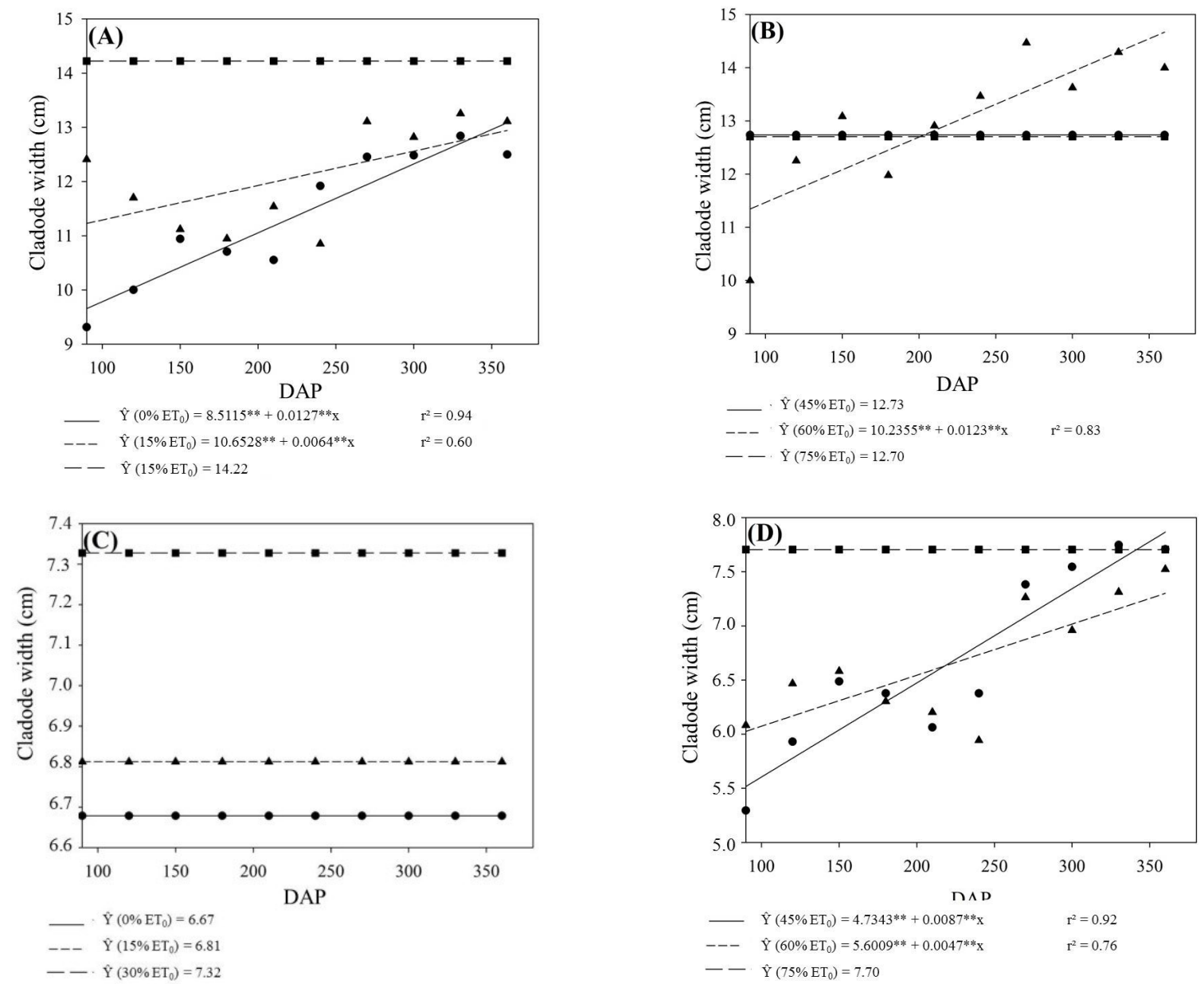

Figure 5. Cladode width over the crop cycle (days after planting - DAP) for water depts based on the $\mathrm{ET}_{0}$ applied through drip irrigation $-0 \%, 15 \%$, and $30 \%(\mathrm{~A}), 45 \%, 60 \%$, and $75 \% \mathrm{ET}_{0}(\mathrm{~B})$ for the cultivar Gigante; and $0 \%, 15 \%$, and $30 \%(\mathrm{C})$, $45 \%, 60 \%$, and $75 \% \mathrm{ET}_{0}$ (D) for the cultivar Miúda.

The maximum cladode area index (CAI) (Figure 6) was $3.67 \mathrm{~m}^{2} \mathrm{~m}^{-2}$ for the cultivar Gigante and $6.53 \mathrm{~m}^{2} \mathrm{~m}^{-2}$ for the cultivar Miúda at 360 days. The maximum CAI daily accumulation was found at 212 DAP for the cultivar Gigante and at 262 DAP for the cultivar Miúda (Figure 6). Increases in CAI are related to high NCP over the crop cycle, which promotes a higher light interception capacity per plant to the photosynthesis, thus stimulating the cactus pear vegetative development.

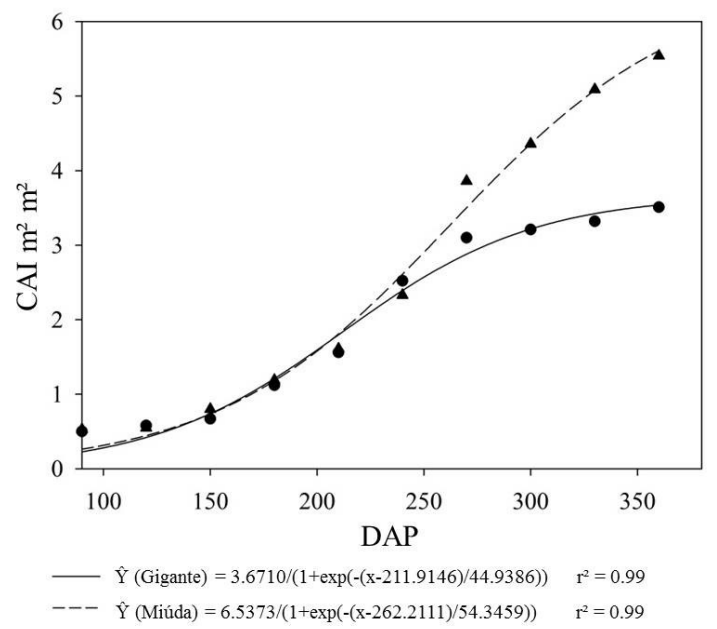

Figure 6. Cladode area index (CAI) over the first crop cycle (days after planting - DAP) for the cultivars Gigante and Miúda. 
According to Ramírez-Tobias, Aguirre-Rivera and Pinos-Rodriguez (2010), cactus pear plants present three growth stages, with approximately 40 days for the Lag stage; 200 days for the exponential growth stage, with increases in the root system and high $\mathrm{CO}_{2}$ absorption; and then, the stabilization stage. This was confirmed for the cultivars evaluated in the present study, allowing the evaluation of cultural practices and analysis of plant production of the species as a result of their photosynthetic capacity and radiation interception and their effects on the final crop production (ADAMI et al., 2008; CARVALHO; OLIVEIRA; PEREIRA, 2011; CEPEDA et al., 2013; ZEGBE; PÉREZ; COVARRUBIAS, 2014). However, CAI varies depending on the genus, clone, and crop conditions, making it an information that allows the evaluation of plant development without the need of knowing the accumulated biomass of the crop (OLIVEIRA JÚNIOR et al., 2009).

According to Silva et al. (2014b) fresh matter yield $\left(\mathrm{Mg} \mathrm{ha}{ }^{-1}\right)$ (FMY) of the cactus pear genera Opuntia and Nopalea were corelated with CAI; they found maximum FMY of approximately $260 \mathrm{Mg}$ ha 1 , which stabilized from this maximum point. This is a similar result to those found in the present study, which showed similar FMY when applying a water depth of approximately $45 \% \mathrm{ET}_{0}$ (Figure 7A). The higher CAI of the cultivar Miúda resulted in a higher dry matter yield (DMY) when compared to the Gigante.

Regarding the productive characteristics and water use efficiency (WUE) of cactus pear, the irrigation water depths $\left(\mathrm{ET}_{0}\right)$ had isolate effect on all variables; and the cultivars (CTV) had isolate effect on DMY and WUE (Table 4).

Table 4. Analysis of variance for fresh matter yield (FMY, $\mathrm{Mg} \mathrm{ha}^{-1}$ ), dry matter yield (DMY, $\mathrm{Mg} \mathrm{ha}^{-1}$ ), and water use efficiency (WUE, $\mathrm{kg} \mathrm{ha}^{-1} \mathrm{~mm}^{-1}$ ) of cactus pear of the cultivars Gigante and Miúda (CTV) under different irrigation water depts $\left(\mathrm{ET}_{0}, \%\right)$.

\begin{tabular}{lcccc}
\hline \multirow{2}{*}{ Source of variation } & \multicolumn{3}{c}{ Mean square } & WUE \\
\cline { 2 - 5 } & DF & FMY & DMY & $167.2248^{* *}$ \\
\hline Block & 3 & $16749.67^{*}$ & $214.46^{* *}$ & $123.2179^{*}$ \\
ET $_{0}$ & 5 & $10690.64^{*}$ & $80.67^{*}$ & 20.71 \\
Error (a) & 15 & 3324.6 & 23.15 & $167.7390^{*}$ \\
CTV & 1 & $6999.39^{\text {ns }}$ & $195.13^{*}$ & $28.4848^{\text {ns }}$ \\
ET $_{0} \times$ CTV & 5 & $5212.55^{\text {ns }}$ & $30.99^{\text {ns }}$ & 35.37 \\
Error (b) & 18 & 4775.9 & 30.79 & 28.22 \\
\hline CV 1 (\%) & & 22.91 & 27.92 & 36.88 \\
CV 2 (\%) & 27.46 & 32.19 & 16.12 \\
General mean & & 251.67 & 17.23 & \\
\hline
\end{tabular}

$\mathrm{DF}=$ degrees of freedom; $\mathrm{ns}=$ not significant, $* *=$ significant at $1 \%$, and $*=$ significant at $5 \%$.

The water depths applied through drip irrigation (Figures 7A and B) affected FMY and DMY; the maximum estimates were $279.28 \mathrm{Mg} \mathrm{ha}^{-1}$ for FMY and $20.17 \mathrm{Mg} \mathrm{ha}^{-1}$ for DMY in the irrigation water depths of $45.2 \%$ and $42.92 \% \mathrm{ET}_{0}$, respectively (Figure 8 ). The DMY of the cultivar

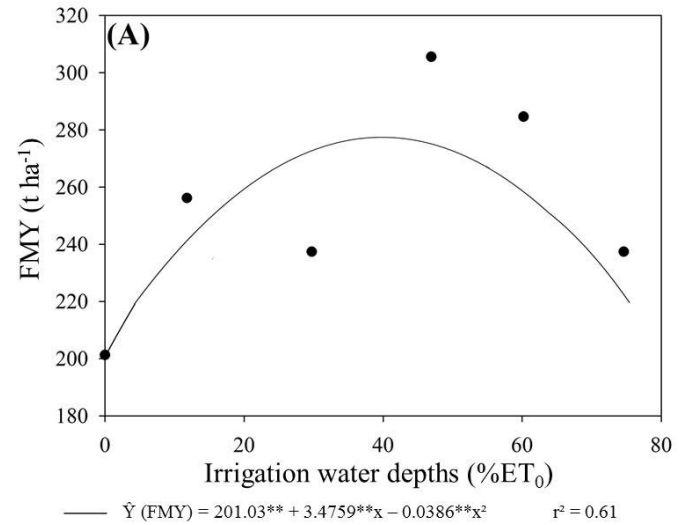

Miúda was significantly different from that of the cultivar Gigante, with mean of $19.25 \mathrm{Mg} \mathrm{ha}^{-1}$ whereas the cultivar Gigante had $15.22 \mathrm{Mg} \mathrm{ha}^{-1}$. FMY and DMY were higher under water depths from 40 to $50 \% \mathrm{ET}_{0}$.

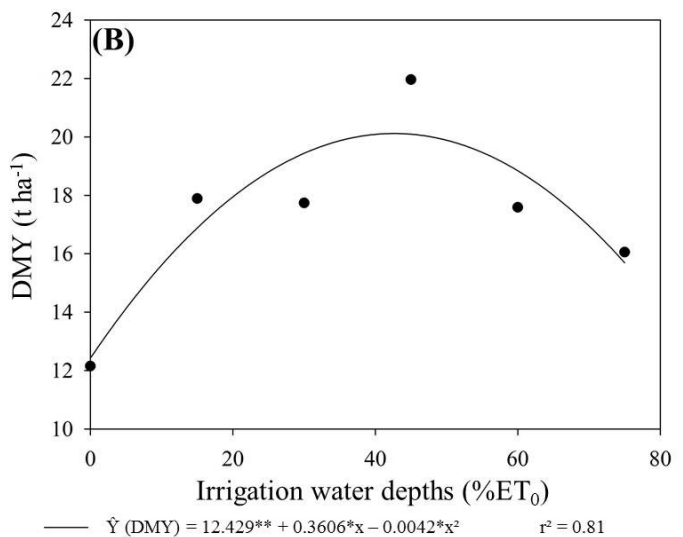

Figure 7. Fresh matter yield (FMY) (A) and dry matter yield (DMY) (B) of cactus pear plants as a function of water depths $\left(\% \mathrm{ET}_{0}\right)$ applied through drip irrigation. 
FMY and DMY increased and subsequent decreased as the water depths were increased, denoting that increases in irrigation water depths above $50 \% \mathrm{ET}_{0}$ do not contribute to increases in crop yield. The morphological characteristics of the cactus pear cultivars were corelated with DMY; clones of plants with higher height and width should be prioritized for selection (SILVA et al., 2010). However, only PH is not enough to affect DMY, as found in the present study; the distance between rows in the subplots did not allow increases in plant width, making them to etiolate. Contrastingly, NCP affected DMY, with the highest NCP of the cultivar Miúda (Figure 3B) resulting in a higher DMY.

Regions with annual rainfall depths above of $1.000 \mathrm{~mm}$ may present low yield due to excess water (OLIVEIRA et al., 2010). This indicates that the yield could be higher than those found (Table 2; Figure 7). The cultivar Miúda (Nopalea sp.) commonly has higher mean dry weight than cultivars of the genus Opuntia (SILVA et al., 2015; LIMA et al., 2016); this was confirmed in the present study. However, the results depend on the crop environment. Cactus pear plants of the cultivar Miúda may present good performance in locations with lower rainfall depths, however, mild temperatures are required, and water availability should be higher in locations with higher temperatures (CRUZ NETO et al., 2017).

Considering the rainfalls occurred, the maximum WUE was $19.17 \mathrm{~kg} \mathrm{ha}^{-1} \mathrm{~mm}^{-1}$ (Figure 8) in irrigation water depth of $15.65 \% \mathrm{ET}_{0}$, regardless of the cultivar. The cultivar Miúda presented higher WUE.

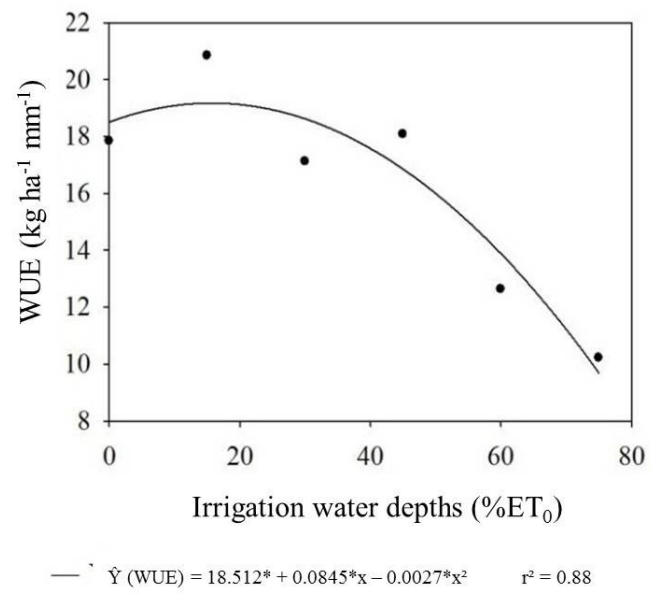

Figure 8. Water use efficiency (WUE), including the rainfalls occurred, as a function of water depths $\left(\% \mathrm{ET}_{0}\right)$ applied through drip irrigation.

Considering the dry weight of plants of the genera Opuntia and Nopalea, they present high WUE (SILVA et al., 2014a), since plants of the Cactaceae family have great capacity to convert water to dry matter because they are CAM plants, i.e., they have high WUE even under low water availability conditions. However, climate conditions, plant spacing, soil fertilization, and clone type affect WUE (DUBEUX JUNIOR et al., 2006). Another factor that affects this variable is the plant's age, as found by Consoli, Inglese and Inglese (2013); they concluded that ten-year-old Opuntia ficus-indica plants presented higher WUE than those in the present study. Moreover, the Gigante cultivar has been highlighted due to its characteristics of $\mathrm{PH}, \mathrm{CL}$, and $\mathrm{CW}$, however, the Miúda cultivar plants compensated these variables with WUE due to its higher NCP, CAI, and DMY; thus, it is the best option to be grown in these conditions.

\section{CONCLUSION}

The irrigation water depths based on the reference evapotranspiration $\left(\% \mathrm{ET}_{0}\right)$ promoted increases in the cactus pear plant height, affecting the length and width of cladodes and not affecting the cladode area index.

The fresh matter and dry matter yields presented best results with use of irrigation water depths of $40 \%$ to $50 \% \mathrm{ET}_{0}$, with better results for the cultivar Miúda.

The water use efficiency of plants of the cultivar Miúda was higher when applying an irrigation water depth of $15.7 \% \mathrm{ET}_{0}$; this cultivar is the most indicated for planting in regions with similar conditions. 


\section{ACKNOWLEDGEMENTS}

Research support of the Minas Gerais Research Funding Foundation (Fapemig), the National Council for Scientific and Technological Development (CNPq), and the Coordination for the Improvement of Higher Education Personnel (Capes), for granting of scholarships.

This study was financed in part by the Coordenação de Aperfeiçoamento de Pessoal de Nível Superior - Brasil (CAPES) - Finance Code 001 .

\section{REFERENCES}

ADAMI, M. et al. Estimativa de área de folíolos de soja usando imagens digitais e dimensões foliares.Bragantia, 67: 1053-1058, 2008.

ALLEN, R. G. et al. Evapotranspiracióndel cultivo: guías para ladeterminación de losrequerimientos de agua de los cultivos. Roma: FAO, v. 298, 2006.

ALVARES, C. A. et al. Köppen's climate classification map for Brazil. Meteorologische Zeitschrift, 22: 711-728, 2013.

AZEVEDO, C. F. et al. Morfoanatomia vegetativa de Opuntia brasiliensis (Willd) Haw. Ambiência, 9: 73-82, 2013.

AMORIM, A. M. et al. Phenophases and cutting time of forage cactus under irrigation and cropping systems. Pesquisa Agropecuária Tropical, 47: 6271, 2017.

ARAÚJO JÚNIOR, G. N. et al. Estresse hídrico em plantas forrageiras: Uma revisão. Pubvet, 13: 1-10, 2019.

BAJGAIN, R. et al. Biomass production and yield of soybean grown under converted paddy fields with excess water during the early growth stage. Field Crops Research, 180: 221-227, 2015.

CARVALHO, A. A. et al. Soil moisture in forage cactus plantationswith improvement practices for their resilience. Revista Brasileira de Engenharia Agrícola e Ambiental, 21: 481-487, 2017.

CARVALHO, D. F.; OLIVEIRA, A. D.; PEREIRA, J. B. A. Ajuste de modelos para estimativa do índice de área foliar e acúmulo de biomassa do pimentão em função de graus-dias. Semina: Ciências Agrárias, 32: 971-982, 2011.

CAVAlCANTE, L. A. D. et al. Respostas de genótipos de palma forrageira a diferentes densidades de cultivo. Pesquisa Agropecuária Tropical,44: 424-433, 2014.

CEPEDA, R. D. V. et al. Fruit weight and number of fruits per cladode depend on fruiting cladode fresh and dry weight in Opuntiaficus-indica(L.) Miller variety 'Rojopelón'. Scientia Horticulturae, 161: 165-169, 2013.

CONSOLI, S.; INGLESE, G.; INGLESE, P. Determination of evapotranspiration and annual biomass productivity of a cactus pear (OpuntiaficusindicaL. (Mill.) orchard in a Semi-arid Environment. Journal of Irrigation and Drainage Engineering, 139: 680-690, 2013

CRUZ NETO, J. F. et al. Aplicabilidade de indicadores agrometeorológicos para análise do incremento de água por irrigação em sistemas de produção da palma forrageira, cv. Miúda. Journal of Environmental Analysis and Progress, 2: 98-106, 2017.

DONATO, S. L. R. et al. Diagnóstico nutricional e recomendação de adubação da palma forrageira 'gigante'. Informe Agropecuário, 38: 46-58, 2017.

DUBEUX JUNIOR, J. C. B. et al. Productivity of Opuntia ficus-indica (L.) Miller under different N and $\mathrm{P}$ fertilization and plant population in north-east Brazil. Journal of Arid Environments, 67: $357-$ 372, 2006.

FERREIRA, D. F. Sivar: a guide for its bootstrap procedures in multiple comparisons. Ciência e Agrotecnologia, 38: 108-112, 2014.

HARGREAVES， G. H.; SAMANI, Z. A. ReferenceCropEvapotranspirationfromTemperature. Applied Engineering in Agriculture, 1: 96-99, 1985.

LIMA, G. F. C. et al. Morphological characteristics and forage productivity of irrigated cactus pear under different cutting intensities. Revista Caatinga, 29 481-488, 2016.

MANTOVANI, E. C. et al. Irrigação: princípios e métodos. 3 ed. Viçosa, MG: Ed. UFV, 2009. 355 p.

MARTIN, J. D. et al. Irrigação deficitária para aumentar a produtividade da água na produção de silagem de milho. Irriga, 1: 192-205, 2012.

MARQUES, O. F. C. et al. Palma forrageira: cultivo e utilização na alimentação de bovinos. Caderno Ciências Agrárias, 9: 75-93, 2017.

NOBEL, P. S. Biologia ambiental. In: BARBERA, G.; INGLESE, P. Agroecologia, cultivo e usos da 
palma forrageira. João Pessoa, PB: SEBRAE/PB, 2001. p. 36-48.

OLIVEIRA, F. T. et al. Palma forrageira: Adaptação e importância para os ecossistemas áridos e semiáridos. Revista Verde de Agroecologia e Desenvolvimento Sustentável, 5: 27-37, 2010.

OLIVEIRA JÚNIOR, $\mathrm{S}$. et al. Crescimento vegetativo da palma forrageira (Opuntia ficusindica) em função do espaçamento no Semiárido paraibano. Tecnologia \& Ciência Agropecuária, 3: 7-12, 2009

PINTO, M. S. C. et al. Estimativa do peso da palma forrageira (Opuntia fícus-indica, Mill.) a partir de medidas dos cladódios. In: Reunião Anual da Sociedade Brasileira de Zootecnia, 39., 2002, Recife. Anais... Recife: SBZ, 2002. p. 54-64.

PEREIRA, P. C. et al. Morfogênese da palma forrageira irrigada por gotejamento. Revista Caatinga, 28: 184-195, 2015.

QUEIROZ, M. G. et al. Características morfofisiológicas e produtividade da palma forrageira em diferentes lâminas de irrigação.

Revista Brasileira de Engenharia Agrícola e Ambiental, 19: 931-938, 2015.

RAMOS, J. P. F. et al. Crescimento vegetativo de Opuntiaficus-indica em diferentes espaçamentos de plantio. Revista Caatinga, 24: 41-48, 2011.

RAMÍREZ-TOBIAS, H. M; AGUIRRE-RIVERA, J. R.; PINOS-RODRIGUEZ, J. M. Productivity ofOpuntiassp. andNopaleasp. (Cactacea) growing under greenhouse hydroponics system. Journal of Food, Agriculture \& Environment, 1: 660-665, 2010.

SANTOS, D. C. et al. Estratégias para uso de cactáceas em zonas Semiáridas: novas cultivares e uso sustentável das espécies nativas. Revista Científica de Produção Animal, 15: 111-121, 2013.

SILVA, J. A. et al. Cultivares e manejo da palma forrageira. Informe Agropecuário, 38: p. 34-45. 2017.

SILVA, L. M. et al. Produtividade da palma forrageira cultivada em diferentes densidades de plantio. Ciência Rural, 44: 2064-2071, 2014a.

SILVA, N. G. M. et al. Relação entre características morfológicas e produtivas de clones de palmaforrageira. Revista Brasileira de Zootecnia, 39: 2389-2397, 2010.
SILVA, T. G. F. et at. Indicadores de eficiência do uso da água e de nutrientes de clones de palma forrageira em condições de sequeiro no Semiárido brasileiro. Revista Bragantia, 73:184-191, 2014b.

SILVA, T. G. F. et al. Área do cladódio de clones de palma forrageira: modelagem, análise $\mathrm{e}$ aplicabilidade. Revista Brasileira de Ciências Agrárias, 9: 633-641, 2014c.

SILVA, T. G. F. et al. Crescimento e produtividade de clones de palma forrageira no semiárido e relações com variáveis meteorológicas. Revista Caatinga, 28: 10-18, 2015.

SOUZA, D. C. F. et al. Zoneamento agroclimático da palma forrageira (opuntia $s p$.) para o estado de Sergipe. Revista Brasileira de Agricultura Irrigada, 12: 2338-2347, 2018.

TAIZ, L.; ZEIGER, E. Fisiologia e desenvolvimento vegetal. 6 . ed. Porto Alegre, RS: Artmed, 2017. 819 p.

TEIXEIRA, P. C. et al. Manual de Métodos de Análise de Solo. 3. ed. Brasília, DF: EMBRAPA, 2017. $577 \mathrm{p}$

VASCONCELOS, A. G. V. et al. Seleção de clones de palma forrageira resistentes à cochonilha-docarmim (Dactylopius sp.). Revista Brasileira de Zootecnia, 38: 827-831, 2009.

ZEGBE, J. A.; PÉREZ, A. S.; COVARRUBIAS, J. M. Mineral nutrition enhances yield and affects fruit quality of 'Cristalina' cactus pear. Scientia Horticulturae, 167: 63-70, 2014. 